\title{
Simulerede krigsteatre
}

\section{Om eksplosionen af slagmarkens tid og rum i Rimini Protokolls Situation Rooms og Harun Farockis Serious Games}

I sin lille, men betydningsfulde bog War and Cinema fra 1984 udforsker filosoffen Paul Virilio, hvordan militære og cinematografiske teknologier møntet på at forme såvel civilbefolkningers som soldaters perception af krig systematisk er blevet bragt i forbindelse med hinanden op igennem det 20. århundrede. Mere konkret peger han dels på, hvordan krigsførende stater fra 1. verdenskrig til slutningen af århundredet systematisk har anvendt filmmediet som propagandaredskab til at sikre sig civilbefolkningers opbakning. Dels bemærker han, hvordan soldaten og piloten i den industrialiserede krigs æra i stigende grad oplever selve krigshandlingen igennem militære synsteknologier og medieringer. Tilsammen, hævder Virilio, har alt dette bidraget til fremkomsten af en militær perceptionslogik møntet på at bearbejde og erobre subjekters sanseapparater: "the history of battle is primarily the history of radically changing fields of perception" (Virilio 1989, 7).

Forsøget på at forme og kalibrere subjekters sanseapparater som en del af krigsførelsen er kun blevet mere udbredt med de alliancer mellem militæret, Hollywood og computerspilproducenter, som især i USA har vundet stadig mere frem op igennem 1990'erne og 2000'erne. I denne artikel ønsker jeg at undersøge, hvilke konsekvenser denne udvikling har for forestillingen om slagmarken og i videre forstand for subjektets perceptive og affektive apparat. Til det formål vil jeg trække på teoriske indsigter af bl.a. Tim Lenoir, der er professor i film og digitale medier, og James Der Derian, der er professor i sikkerhedsstudier. Desuden vil begrebet om krigsteater, som defineret af den prøjsiske general og militærteoretiker Carl von Clausewitz, fungere som et centralt redskab i forhold til at lokalisere nogle af de forandringer i krigsførelsens rumlige og tidslige logik, som skiftet fra Napoleonskrigene til nutidens brug af simuleringer og medieringer som en integreret del af krigsførelsen har medført. Til at konkretisere alt dette vil jeg analysere to værker, der begge kan betegnes som en slags krigsteatre en miniature, nemlig det tyske teaterkollektiv Rimini Protokolls performative installation Situation Rooms og den tyske dokumentarfilmkunstner Harun Farockis video-installation Serious Games. Ud over at illustrere den 
nævnte udvikling igennem de to værker, vil en central ambition være at argumentere for, hvordan værkernes kombination af dokumentariske og teatrale greb kan anskues som et adækvat greb i forhold til kritisk at beskæftige sig med den nye, simulerede krigsvirkelighed.

\section{Virtuelle krige vis-a-vis selvberoende krigsteatre}

Under indtryk af den teknologisk stadig mere avancerede form for krigsførelse, som 1990'ernes såkaldte "Revolution in Military Affairs" (RMA) ${ }^{\mathrm{I}}$ har resulteret i, har skikkelser som bl.a. Tim Lenoir og James Der Derian videreført og opdateret Virilios indledningsvis nævnte overvejelser om filmindustrien og militærapparatets uhellige alliance. Tilbage i 2000 kortlagde Lenoir som en af de første således det tætte samarbejde mellem ikke bare militæret og filmindustrien, men også spil-industrien, som er fulgt i kølvandet på det amerikanske militærs teknologiske oprustning. Bl.a. påviste han, hvordan det i 1999 oprettede Institute for Creative Technologies (ICT) på University of Southern California har dannet rammen om et tæt samarbejde mellem militæret, universitetsforskere, Hollywoodproducenter og spiludviklere. Et samarbejde, der har resulteret i udviklingen af en række immersive simulationsspil møntet på såvel militær brug som kommercielle sammenhænge. Nok så vigtigt redegjorde han for, hvordan en stor del af forskningen på centret er finansieret af militæret. I forlængelse heraf taler Lenoir om fremkomsten af et "militært-underholdningskompleks" (frem for det velkendte militær-industrikompleks) og vover en forudsigelse:

66 As we come to entrust more of our lives to Internet communications, and as we spend more time in virtual, electronic space, our notions of materiality and reality will inevitably change. (Lenoir 2000, 290)

I sin bog Virtuous War fra 2009 fortsætter Der Derian denne undersøgelse, men topper så at sige Lenoir ved at foreslå betegnelsen "militært-industrielt-medie-underholdnings-netværk" som passende betegnelse for nutidens krigsmiljø. Videre foreslår han begrebet virtuous war som betegenlse for krig i en tid, hvor computersimulering, medialisering, global overvågning og netværksbaseret informationsteknologi er dybt indfiltret i hinanden. En æra, hvor krige - den første Golfkrig er måske det bedste eksempel - forsøges markedsført som humanitære nålestiksoperationer og som noget, der ikke involverer blod eller tab. I Der Derians vokabular dækker adjektivet virtuous således både over krigens stadig mere virtuelle karakter, men også over de diskurser, der forsøger at sælge den som "dydig" i betydningen humanitær og etisk (Der Derian 2009, xxxi-xxxii). I forlængelse heraf påpeger Der Derian, hvordan nye imitations- og simulationsteknologier sammen med overvågning i stigende grad har eroderet geografiske afstande, kronologisk tidslighed og i sidste instans skellet mellem virkelighed og virtualitet (Der Derian 2009, 10).

Såvel Virilio som Lenoir og Der Derian hæfter sig altså ved, at et vigtigt element i det 20. og 21. århundredes krigsførelse er erobringen af subjektets perceptions- og i videre forstand, kunne man hævde, faktisk også forestillingsevne via cinematogra- 
fiske og simulerede billeder. At billeder bruges instrumentelt i forbindelse med krig, er der for så vidt intet nyt i. Tænk bare på de antikke græske vasers mytologiske slagscene-motiver, de romerske triumfbuers afbildning af historiske slag, middelalderens Bayeuxtapet, baroktidens allegoriske bataljemalerier eller Napoleontidens afbildninger af Napoleon som den heroiske general til hest. ${ }^{2}$ Alle repræsenterer de typisk sejrherrens perspektiv, ligesom de groft sagt har til hensigt at fremme den ideologi og de værdier, som sejrherren, der typisk er den, der har bestilt og betalt for slagscenemotivet, repræsenterer. Det samme princip er for så vidt på spil i nutidens fotojournalistiske krigsreportager, der typisk er stramt kontrolleret af militæret. Tag de næsten sanitære videobilleder af såkaldte præcisionsbombninger optaget fra amerikanske bombefly under den 1. Golfkrig, eller tag den såkaldte "embedded journalism" under Irakkrigen i 2005, hvor vestlige journalister og fotografer blev udsendt sammen med soldater fra "De villiges koalition". I begge tilfælde var de billeder og historier, der ramte den globale medieoffentlighed, underlagt og farvet af et specifikt vestligt perspektiv. For at bruge Judith Butlers berømte formulering er de krige, der fra vestlig side er blevet ført i kølvandet på 9/11 ved hjælp af embedded journalism, blevet formidlet igennem nogle rammer, der umærkeligt har distribueret værdi til nogle liv og frataget andre værdi i en grad, så tabet af disse liv er blevet betragtet som "ikke-sorgbart" (Butler 2009, 38).

Noget af det, der springer i øjnene som nyt eller anderledes ved den nutidige højteknologiske krigsmaskines måde at kalibrere og forme såvel civilbefolkningers som soldaters sanseapparat og forestillingsevne, synes imidlertid at være forbundet med den ophævelse af tidslig kronologi og spatial afgrænsning af slagmarken fra civilsamfundet, som Der Derian noterer, er karakteristisk for virtuous war. Til forskel herfra definerede den prøjsiske general og militærteoretiker Carl von Clausewitz tilbage i 1800-tallet, under indflydelse af Napoleon-krigenes slag mellem store hære, slagmarken som en afgrænset, selvberoende enhed. Han skriver:

46 By 'Theatre of operations' (tysk: 'Kriegstheater') we mean, strictly speaking, a sector of the total war area which has protected boundaries and so a certain degree of independence. This protection may consist in fortifications or great natural barriers, or even in a substantial distance between it and the rest of the war area. A sector of this kind is not just a part of the whole, but a subordinate entity in itself - depending on the extent to which changes occurring elsewhere in the war area affect it not directly but only indirectly. (Clausewitz 1976, 280 - mine fremhævelser)

I Clausewitz' forståelse udgør krigsteatret altså det rumligt-geografiske territorium, hvor kampen finder sted. Samtidig dækker begrebet over eksistensen af adskillige, sideløbende krigsteatre, der i sig selv udgør små, afgrænsede helheder. Afgrænsede helheder, der følger deres egne regler og kun griber indirekte ind i hinanden.

Clausewitz' beskrivelse af slagmarken som et Kriegstheater vækker muligvis undren. Men fra 1500-tallet og frem til Clausewitz blev væbnede kamphandlinger og slag, såvel i krigsberetninger som i militærjargon, typisk fremstillet ved hjælp af teatrale metaforer. Som redegjort for af bl.a. historiker Marian Füssel blev slagmarken i 1500- og 1600-tallets skriftlige beretninger således rutinemæssigt fremstillet som 
en scene, soldater som aktører og nederlag som tragedier (Füssel 2008, 216). Krigen blev med andre ord konciperet og fremstillet som et udgrænset udsnit af virkeligheden, der følger sine egne regler og sit eget narrativ. I tråd hermed, påpeger Füssel, blev slagmarken i datidens visuelle skildringer, som fx kobberstik, typisk refereret til som "skueplads" eller "teater", ligesom den blev fremstillet som en overskuelig og geometrisk ordnet helhed, typisk afbildet fra generalens altseende perspektiv fra toppen af en bakke (Füssel 2008, 215). Ser man til det vestlige teater er det, som påpeget af teaterforsker og dramaturg Thomas Oberender, muligt at trække en interessant parallel til det ideal om det absolutte drama, der manifesterer sig i samme periode (Oberender 2006, 18).

Som litteraturhistoriker Peter Szondi har argumenteret for med stor resonans, præges det litterære, vestlige teater fra renæssancen og frem til slutningen af 1800-tallet nemlig af et dramaturgisk ideal, der prioriterer dramaets autonomi og symmetri. Modsat fx det antikke græske dramas brug af episke elementer som korsekvenser og parabase, det elizabethanske teaters direkte publikumshenvendelser eller barokteatrets indlemmelse af publikum på scenen, skal dramaet ifølge dette ideal udgøre sin egen, fra publikum afsondrede enhed. Det skal så at sige danne sit eget "nu", sin egen virkelighed; hændelserne i dramaet skal følge kausal-logisk på hinanden, og endelig skal tidens, stedets og handlingens enhed overholdes (Szondi 1967, 16-18). Samtidig er dramaets grundstof, ligesom det er tilfældet for krigen, konflikt. Konflikt, konfrontationer mellem mennesker og omstændigheder, der efter krigens eller dramaets udgang typisk er grundlæggende forandrede fra dem, der herskede ved dets begyndelse, er så at sige hovedingredienserne i dette drama.

Snarere end at udgøre en reel beskrivelse af slagmarkens eller dramaets logik kunne man imidlertid hævde, at Clausewitz' definition af krigsteatret og det dramatiske ideals fordring om autonomi måske mest af alt udgør - et ideal. Et ønske om at kunne indstifte en form for orden og logik i en uforudsigelig og voldelig tilstand præget af konflikt og kaos. ${ }^{3}$

Vender vi os mod nutiden, er der ikke så overraskende nogle ganske andre forestillinger på færde om såvel krigens som teatrets rumlighed og temporalitet. Imidlertid har teatermetaforikken, som efter Clausewitz kom til at indtage en langt mindre prominent plads end tidligere (Füssel 2008, 223), oplevet en genopblomstring i forbindelse med den medialisering og virtualisering af krig, der har fundet sted i sidste del af det 20. århundrede. ${ }^{4}$ Dog taler man i dag snarere om spektakelkrige end om krigsteatre. Den britiske freds- og konfliktforsker Mary Kaldor, der med inspiration fra såvel Guy Debord som Jean Baudrillard lancerede begrebet tilbage i starten af 2000'erne, definerer spektakelkrig således:

66 RMA (Revolution in Military Affairs) is spectacle war, it is carried out at long distance using computers and new communications technologies. [...] An important aspect of the new technologies is the improvement in virtual war gaming, which further underscores the imaginary nature of spectacle war. (Kaldor 2007, 85)

Kaldor understreger altså den imaginære kvalitet ved den højteknologiske krig-påafstand, og noterer sig i forlængelse heraf, hvorledes beskueren til denne krig, mere 
specifikt den amerikanske borger plantet foran en CNN live-transmission, så at sige afkobles emotionelt fra det, hun ser, netop pga. krigens medialiserede karakter.

At den medialiserede repræsentation af krigen er blevet en lige så central del af konflikten som den kamp, der udspilles på den konkrete, territoriale slagmark, bekræftes af de billedkrige, som såvel vestlige koalitioner som løst organiserede terrornetværk har ført siden starten af 2000'erne. ${ }^{5}$ De ofte chokerende visuelle repræsentationer af krig og konflikt og cirkuleringen af disse repræsentationer på tværs af mainstream og sociale medieplatforme er så at sige blevet et yderst effektivt våben $\mathrm{i}$ forhold til at forme det globale mediepublikums sanseapparat og forestillingssevne (Mitchell 2011, 2-3; Roger 2013, 46; Mirzoeff 2005, 69).

I forhold til den tidligere skitserede forståelse af krigsteatret som en afgrænset, selvberoende enhed, kan man således opsummerende sige, at den forståelse i dag synes at være blevet erstattet af et billede af krig som noget, der udfolder sig simultant $\mathrm{i}$ et netværk af internt forbundne rum, der spænder fra fysiske territorier til digitale og virtuelle sites. Indenfor teatret er idealet om det absolutte drama og det autonome teaterrum på lignende vis blevet udfordret og eksploderet op igennem det 20. og 21. århundredes teater med fremkomsten af bl.a. stedsspecifikt, deltagerorienteret, immersivt og postdramatisk teater. ${ }^{6}$ Ikke desto mindre, vil jeg hævde, ligger ideen om såvel krigsteatret som teatret som et afgrænset rum, der følger sine egne, autonome regler, som en klangbund, vi konstant definerer os op imod, når vi fors $\varnothing$ ger at begribe såvel nutidens medialiserede og virtuelle krigsførelse som samtidens post-dramatiske teater. Nok så vigtigt for mit ærinde synes teatralitetsmetaforen, mere specifikt iscenesættelsesdimensionen og castingen af os selv og fjenden i forskellige roller, stadig at være yderst relevant i forhold til at begribe de måder, hvorpå krig føres i dag.

I det følgende vil jeg undersøge, hvordan netop teatralitet udforskes i Rimini Protokolls immersive installation Situation Rooms og Harun Farockis videoinstallations-serie Serious Games, der begge beskæftiger sig med virtuel krig. I forlængelse heraf vil jeg argumentere for, at de to værkers kobling af teatrale og dokumentariske greb i den midlertidige afsondrede helhed, kunstrummet udgør, kan anskues som et forsøg på at få beskuerne til at sanse den simulerede slagmark, de bevæger sig igennem i værkerne, som materiel og virkelig.

\section{Indlejret i våbenindustrien}

Det tysk-schweiziske instruktørkollektiv Rimini Protokoll har igennem deres omfattende værk arbejdet konsekvent med at udforske virkelighedens grundlæggende teatrale karakter. Dette har de typisk gjort med inddragelse af såkaldt virkelige mennesker, dvs. ikke-uddannede skuespillere, som en form for levende dokumenter på scenen. I deres storstilede immersive installation Situation Rooms fra 2013 tager Rimini Protokoll igen udgangspunkt i 'virkelige menneskers' beretninger, men denne gang overlader de scenen til publikum, der så at sige får til opgave at spille disse menneskers roller.7 Omdrejningspunktet for projektet, der i programmet lanceres som et "multiplayer videostykke", er forbindelsen mellem krig og våbenindustrien. 


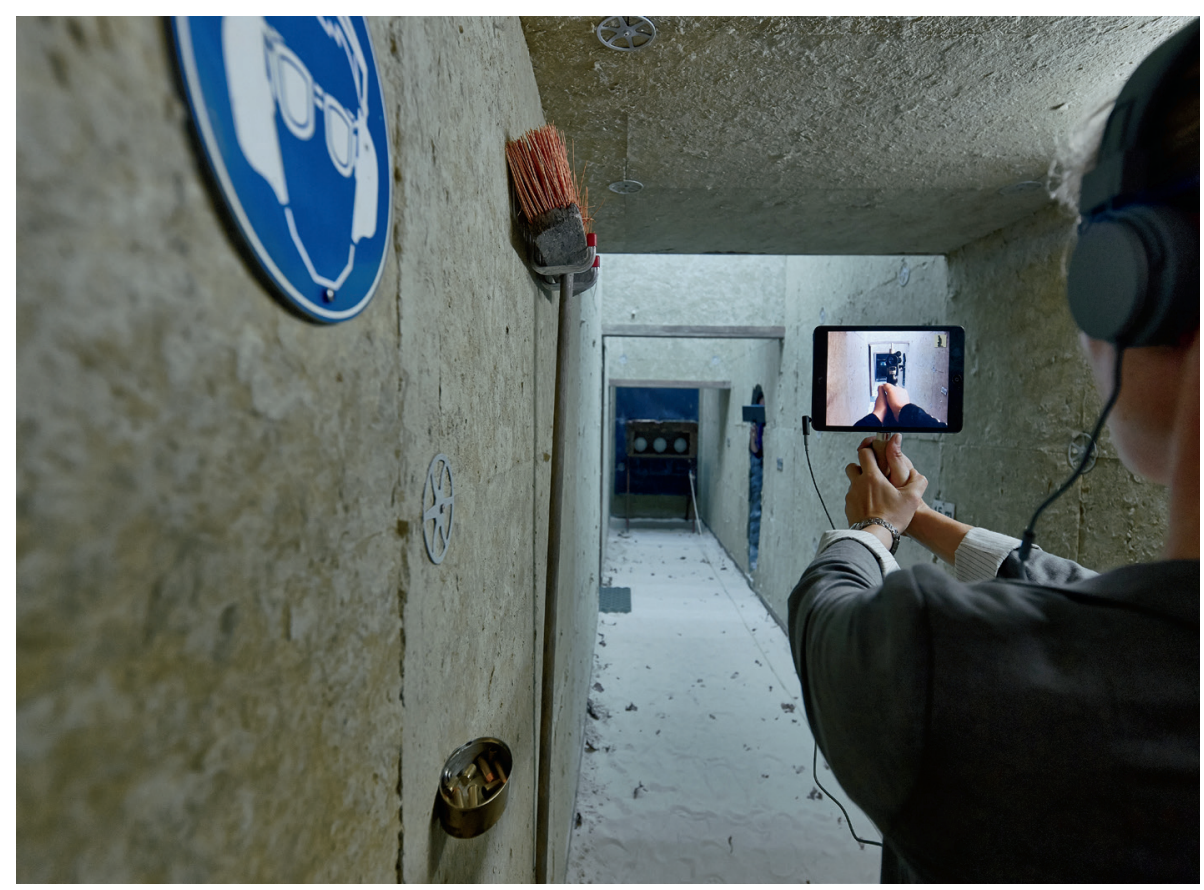

Rimini Protokoll: Situation Rooms. Photographed by Jörg Baumann / Ruhrtriennale 2013

I Situation Rooms sammenstilles tyve personlige beretninger, der har det til fælles, at de alle på den ene eller anden måde er formet af våbenindustrien. ${ }^{8}$ Protagonisterne, der både tæller mennesker, der producerer og bruger våben, og mennesker, der er ofre for disse våben, kommer fra hele verden. Således lytter vi til beretninger af bl.a. en indisk droneoperatør, en pakistansk advokat, der repræsenterer civile ofre for droneangreb, en tysk krigsfotograf, en congolesisk, tidligere børnesoldat, en libysk familie på flugt og en tysk direktør for forsvarssystemer. Protagonisterne er som sagt ikke til stede i rummet med os, men optræder i stedet i tyve forskellige film, der hver er syv minutter lange, og alle er optaget i den filmset-lignende installation. Installationen rummer i alt femten rum, herunder en dronestation i Indien, et klasseværelse i Congo, en gade i Homs i Syrien, en mexicansk kirkegård og en våbenmesse i Abu Dhabi. Hvad angår beskuerne, så udstyres de ved ankomsten med iPad og hovedtelefoner og bliver derefter placeret foran hver deres dør til installationen. Forestillingen begynder, da publikum med ipad'en som guide i hånden begynder at bevæge sig igennem, eller måske snarere at re-enacte, de forskellige protagonisters ruter. Jeg startede fx i et hyper-realistisk indrettet operationsværelse i Sierra Leone. Her lyttede jeg med blikket kløvet og konstant pendulerende mellem iPadens virtuelle gengivelse af dette rum (filmet fra protagonistens perspektiv) og det virkelige rum, jeg selv befandt mig i, koncentreret til den tyske operationslæges voldsomme beretning om sin udstationering i Sierra Leone. Samtidig havde jeg travlt med at udføre de ordrer, han gav mig, som fx at lægge mig op på operationsbriksen. Og pludselig, efter syv minutter, var den simulerede virkelighed, jeg var blevet nedsænket i, slut, og jeg måtte bevæge mig videre til det næste rum, den næste protagonist, den næste historie.

Forestillingens titel er inspireret af Pete Souzas berømte foto fra 2011 taget i The Situation Room i Det Hvide Hus. Fotoet blev taget under den såkaldte operation 


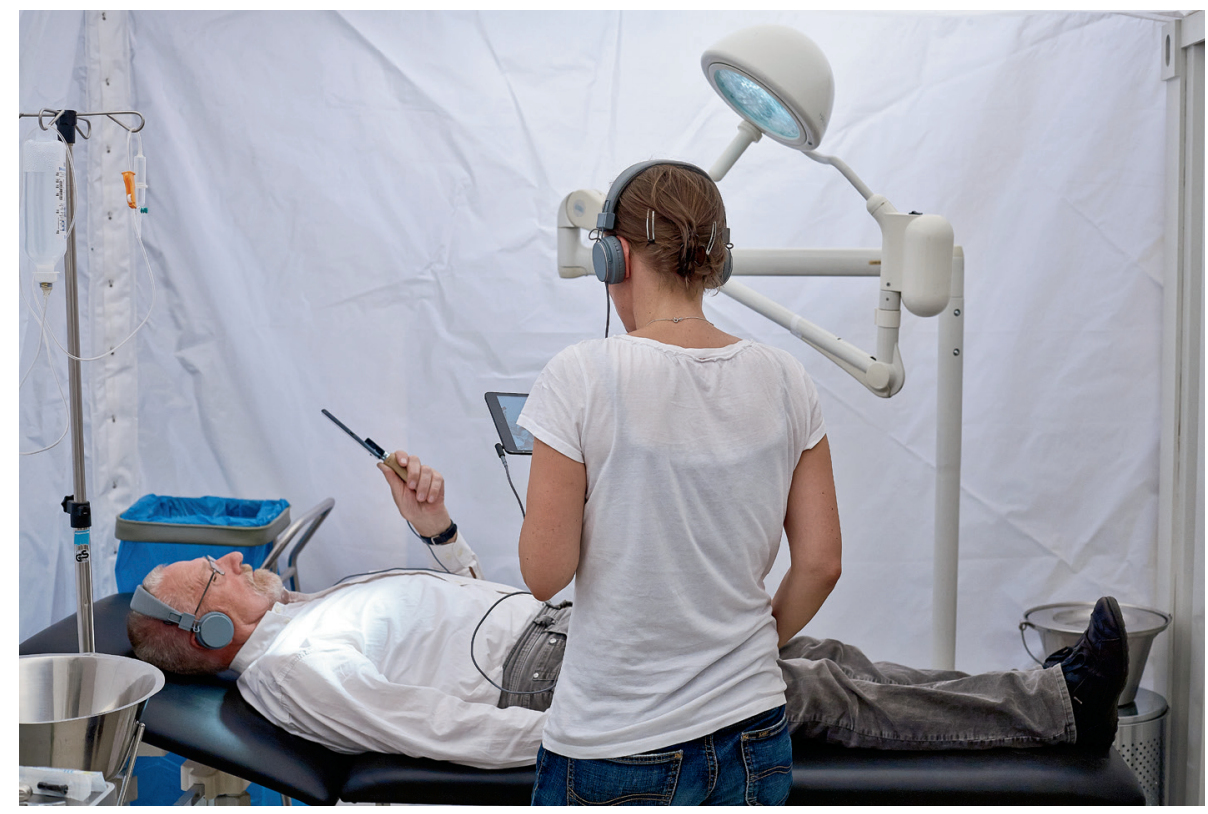

Rimini Protokoll: Situation Rooms. Photographed by Jörg Baumann / Ruhrtriennale 2013

Neptune Spear, der førte til drabet på Osama bin Laden, og afbilder den amerikanske præsident Barack Obama, vicepræsident Hillary Clinton og det nationale sikkerhedsteam, mens de fra situationsrummet i Det Hvide Hus følger missionen i realtid. Som Nikolaus Hirsch skriver i forestillingsprogrammet til Situation Rooms, kom situationsrummet oprindeligt i stand på John F. Kennedys initiativ ovenpå det amerikanske militærs mangel på aktuelle informationer under invasionsfors $\varnothing$ get af Cuba i 1961. Ideen med situationsrummet var derfor ved hjælp af avanceret teknologi at sammenbringe ellers usammenhængende aktuelle begivenheder i et lukket, ikkeaflytteligt rum, hvorfra man kunne overskue og påvirke dem (Hirsch 2013, 7-8). Det ligger lige for at forestille sig dette situationsrum som en teknologisk opdateret version af den clausewitzeanske idé om det afgrænsede krigsteater, som generalen med sit olympiske blik kan overskue fra toppen af bakken.

Med hilsen hertil opstilles der i Rimini Protokolls forestilling en række situationsrum. En vigtig forskel er imidlertid, at Rimini Protokoll har forladt idéen om ét privilegeret rum eller perspektiv til fordel for en række simultant eksisterende rum, deraf også forestillingstitlens pluralis-form. Rum, der nok er struktureret af hver deres handlingslogik, men som ved nærmere eftersyn viser sig at være intimt forbundne igennem våbenhandlens voldelige, økonomiske logikker. Ved i installationen helt konkret at placere disse rum ved siden af, ovenpå og nedenunder hinanden og ved at forbinde dem via trange korridorer og hemmelige døre blotlægger Situation Rooms således ellers skjulte forbindelser og slægtskaber i krigens globale og vidtforgrenede netværksstruktur. Fx relationen mellem det guldudsmykkede våbenmesserum i Abu Dhabi og det nedslidte klasseværelse i Congo, hvorfra en gruppe drenge bortføres og hverves som børnesoldater.

Alt dette har man imidlertid ikke tid til at tænke nærmere over, imens man bevæger sig igennem installationen. Omsluttet af film-settets simulerede virkelighed får man konstant udstukket opgaver: Find en hemmelig dør, læg en USB-nøgle i en 
kittel, der gemmer sig i et skab, ifør en anden beskuer en beskyttelsesvest, kast dig ned under bordet, for der er nogen, der skyder udenfor etc. etc. Hos mig fremkaldte de mange instruktioner sammen med det kløvede blik, jeg pga. ipad'en oplevede verden igennem, og endelig det faktum, at min færden blev registreret af adskillige overvågningskameraer, en markant følelse af stress og hektik. I overensstemmelse hermed bemærker dramaturg Immanuel Schipper om dramaturgien i Situation Rooms, at:

46 The system works like a clock. It does not stop. Either you are following the trace and the pace or you are out. The grade of freedom in the offer to participate is small here - it is more an invitation to step into a pre-produced role than to take the position of the protagonist - like a prompter guides an actor through the performance. (Schipper 2017, 204)

Schipper har ganske ret; modsat de immersive teaterforestillinger, der det sidste årti har gået deres sejrsgang i Europa og USA, overlades der ikke megen frihed til beskueren i Situation Rooms. Hvor fx grupper som engelske Punchdrunk eller dream-thinkspeak i deres fascinerende rumlige interiører opfordrer tilskuerne til at bevæge sig eksplorativt omkring på egen hånd, så styres de benhårdt i Situation Rooms. ${ }^{9}$ Idet Rimini Protokoll på denne måde kombinerer et "immersions-greb", som inden for teaterverdenen er kommet til at konnotere frihed til beskueren, med et stramt og topstyret regelsæt for, hvordan man skal bevæge sig i det rumlige miljø, man er omsluttet af, opstår der så at sige et illusionsbrud. Man gøres opmærksom på, hvordan ens handlinger netop ikke udspringer af en selv, men derimod er strengt koreograferede af forestillingens instruktør. Sagt på en anden måde iscenesættes man som en brik i et større og ovenfra instrueret krigsspil, hvis struktur man umuligt kan overskue omfanget af fra den partikulære position, man indtager.

Samtidig med at forestillingen på denne måde diskret peger på kontingensen ved de forskellige protagonisters perspektiv, synes den i kraft af sin ikke-absolutte dramaturgiske struktur at mime de, af Der Derian identificerede, særlige temporale og spatiale forhold ved nutidens krigsførelse. Fremfor et lukket, afgrænset krigsteater har vi i forestillingen en mangfoldighed af rum, der forbinder sig på tværs af geografiske, fysiske og virtuelle grænser. Ligeledes har vi i stedet for en lineær begyndelse-midte-slutning-dramaturgi at gøre med en temporalt kompleks dramaturgi, der implicerer, at beskuerne bevæger sig simultant i forhold til hinanden inden for rammerne af hver deres fortælling. Samtidig oplever de også at blive spolet både frem og tilbage i tid, når de møder protagonister, de tidligere selv har inkarneret. Vi befinder os med andre ord ganske langt fra det absolutte dramas kausal-logiske dramaturgi og overholdelse af tidens, stedets og handlingens enhed. I stedet for én samlet fortælling præsenteres vi således for et kalejdoskopisk netværk af tilsyneladende uforbundne beretninger (der dog er forbundet af krigens økonomiske og voldelige logik). Og ved forestillingens afslutning er der da heller ikke vendt op og ned på de kræfter, der ved dramaets begyndelse stod over for hinanden, således som det af Szondi beskrevne dramatiske ideal fordrer.

Slutscenen samler imidlertid for et øjeblik de mange perspektiver. Her forsamles forestillingens tyve beskuere i et mødelokale med et stort mødebord og et verdens- 
kort på væggen. Som i de tidligere scener følger man sin protagonists perspektiv på ipad'en, men pludselig panorerer kameraet ud i rummet og viser de nitten $\emptyset$ vrige "oprindelige" protagonister bevæbnet med hver deres ipad. Kort efter bliver vi opfordret til at holde ipad'en, hvorpå der i mellemtiden er tonet et portræt af den sidste figur, vi har inkarneret, frem, op foran os. Et øjeblik åbner der sig et surrealistisk moment, hvor de fraværende protagonister synes nærværende sammen med os, der midlertidigt har beboet dem. Først nu efterlades der plads til at reflektere over de mange forskellige perspektiver, man har indtaget, såvel mentalt som fænomenologisk, og måske endda identificeret sig følelsesmæssigt med. Men pludselig begynder portrætterne med stor hastighed at cirkulere mellem skærmene, der snart bliver sorte, hvorefter publikum opfordres til at forlade installationen. Krigen og dens simulationer fortsætter, synes forestillingens sidste budskab at være.

\section{Slagmarken i sindet}

Den tyske film- og installationskunstner Harun Farocki beskæftigede sig igennem sit vidt forgrenede værk, fx i Nicht löschbares Feuer (1969) eller Auge/Machine I-III (2001-3), med sammenhængen mellem krigsbilleder og de større statspolitiske og masse-mediale strukturer og logikker, sådanne billeder er indlejret i. I video-installationen Serious Games (2009-10), som det her skal handle om, udforsker og adresserer Farocki kritisk den stadig mere virtuelle karakter ved nutidig krigsførelse. Mere specifikt interesserer han sig for samarbejdet mellem det amerikanske militær, universitetsverdenen og underholdnings- og spilindustrien. Samt for militærets brug af immersive computerspil og simulationer til at ruste - og siden traume-behandle soldater til krig.

Installationen består af fire værker, nemlig Watson is Down, Three Dead, Immersion og A Sun without Shadow. ${ }^{\text {.0 }}$ Den første video viser, hvordan en flok rekrutter inden deres udsendelse til Afghanistan bliver trænet i samarbejde og i at håndtere stressfyldte situationer igennem cyberspillet Virtual Battle Space II. Den anden skildrer et oprørsangreb i en simuleret irakisk by. Den tredje video dokumenterer en terapeutisk session, hvor det immersive virtual reality-system Virtual Iraq anvendes til at behandle en tilsyneladende PTSD-ramt soldat. Endelig foretages der i den fjerde film en sidestilling af materiale fra første og tredje video, og der gøres subtilt opmærksom på, at solen ikke kaster nogen skygge i Virtual Iraq, da systemet til behandling af PTSD-ramte soldater er en anelse billigere end det system, der skal forberede soldater på udsendelse.

Som antydet er Serious Games-serien baseret på dokumentarisk materiale. Således er Watson is Down optaget i 2009 under en øvelse med en gruppe unge soldater på Marine Corps base 29 Palms i Californien. Immersion dokumenterer for sin del en demonstration af Virtual Iraq under en workshop organiseret af det tidligere nævnte Institute for Creative Technologies (ICT) på University of Southern California. Vi er med andre ord helt inde i hjertet af Der Derians militær-industrielle-medie-underholdnings-netværk. Albert "Skip" Rizzo, professor i psykiatri og leder af afdelingen for Medical Virtual Reality på ICT, optræder endog i den fjerde video, hvor han demonstrerer de forskellige funktioner i Virtual Iraq. I udviklingen af det terapeutiske 
spil tog Rizzo oprindeligt udgangspunkt i videospillet Full Spectrum Warrior og simulationssystemet Virtual Vietnam (Halpern 2008). Ved at kombinere en simuleret version af Irak, som soldaten så at sige nedsænkes i med hele sit sanseapparat, med eksponeringsterapi er hensigten med Virtual Iraq at give den PTSD-ramte soldat mulighed for såvel mentalt som fænomenologisk at genbesøge den traumatiske begivenhed. Som Rizzo udtaler i en video produceret af ICT, vil tilpas mange genbes $\varnothing \mathrm{g}$ af den traumatiske begivenhed med tiden resultere i en betragtelig reduktion af den angst, den PTSD-ramte soldat lider af. ${ }^{\text {II }}$

Lad os på den baggrund nu vende os mod slagmarken eller krigsteatret, sådan som det fremstilles og formateres i Serious Games. Studerer man det computer-animerede landskab, de unge rekrutter bevæger sig igennem i Watson is Down, forekommer Der Derians udsagn om, at det virtuelle og det virkelige i stigende grad filtres ind i hinanden i nutidens krigsførelse, absolut legitimt. Som det forklares i de tekster, der løbende dukker op på skærmen, er det simulerede landskab nemlig baseret på kartografiske, geografiske data fra Afghanistan. Og på Farockis hjemmeside uddybes det yderligere, at: "A street in the computer landscape runs exactly as it would in the real Afghanistan, the same holds for every tree, the vegetation on the ground or the mountain ranges". ${ }^{12}$ Den vej, rekrutternes konvoj kører på i simulationen, findes altså i Afghanistan i virkeligheden, hvor den bugter sig på præcis samme måde som i simulationen.

Værket er bygget op omkring en splitscreen-æstetik, der bevirker, at vi som beskuere på den ene skærm oplever simulationens animerede virkelighed set fra soldaternes perspektiv. På den anden skærm derimod er rekrutterne og deres underviser filmet udefra, imens de siddende foran computere navigerer igennem et virtuelt Afghanistan. Således overværer vi, hvordan underviseren fra sin computer så at sige får det simulerede landskab til at performe ved at udstyre det med forskellige uforudsete udfordringer, såsom vejsidebomber og "fjender". For en af disse fjender, en snigskytte, lykkes det rent faktisk at slå den unge rekrut og gunner Watson ihjel. Dette giver imidlertid ikke anledning til de store emotionelle udbrud fra Watsons side. Han nøjes blot med at skubbe sin kontorstol væk fra computeren med en træt mine. Som flere har bemærket (Engberg 2017, 158-159; Verwoert 2011, 29), er det mest slående ved videoværket faktisk den uengagerede attitude, de unge rekrutter

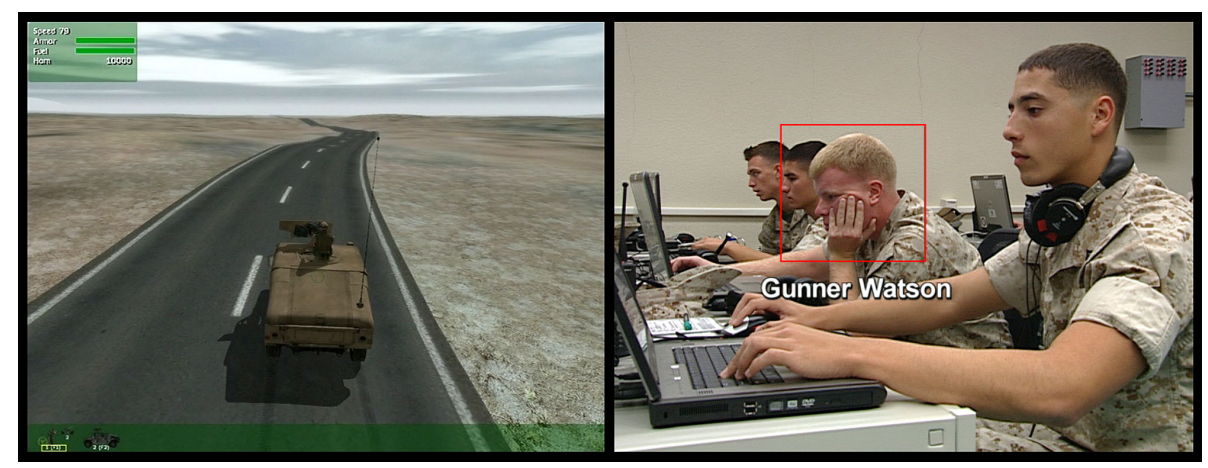


lægger for dagen. De emmer formelig af kedsomhed, på trods af at de bevæger sig igennem et fjendtligt landskab, hvor døden synes at lure om hvert hjørne.

Fuldstændig modsat forholder det sig i værket Immersion. Her oplever vi veteranen Kevin genopleve den smertefulde og traumatiserende oplevelse, det var, da han under en rutinepatrulje i Irak oplevede sin makker blive sprængt i stumper og stykker. Forud for genbesøget af den traumatiske oplevelse er Kevin blevet udstyret med avanceret Virtual Reality-udstyr. Således gør VR-briller ham i stand til på meget livagtig vis at se de landskaber, han bevæger sig igennem. Høretelefoner udstyrer ham med lyden af vind, larm fra helikoptere, skud, eksplosioner. Og den platform, han står på, sender forskellige sanselige stimuli igennem hans krop, der fx giver ham fornemmelsen af at køre på en bumlet vej. Som film- og medieforsker Daniel Grinberg bemærker i en læsning af værket, har denne vægtning af det sensoriske aspekt til hensigt at katalysere traumet på en måde, der går ud over den optiske genkaldelse. Som Grinberg skriver:

64 By mimetically reproducing the bodily sensations to Iraq war veterans, the technology is drawing on a phenomenological realism to help the participants access otherwise inaccessible knowledge. (Grinberg 2016)

På værkets ene skærm oplever vi fra Kevins perspektiv den simulerede version af Irak (om end vi modsat Kevin kun får den optiske version med). På den anden skærm ser vi den halvt-menneske-halvt-maskine-lignende Kevin interagere med en kvindelig psykolog, der presser ham til at bevæge sig ind i den smertefulde erindring, selvom han så mindeligt beder om at få lov til at slippe. Alt imens hun styrer ham igennem forskellige simulerede landskaber, spørger hun til hans oplevelse af ubehag på en skala fra 1 til 100. Og først da han knælende på gulvet gør opmærksom på, at han skal kaste op, ligesom han skulle dengang i Irak, afbryder hun sessionen. Da jeg oplevede installationen, følte jeg på dette tidspunkt selv en lettere kvalme. Jeg formoder, den dels var fremkaldt af at kigge på det gyngende computerlandskab fra Kevins perspektiv, dels af den bizarre kontrast, der var mellem den grotesk udseende cyborgfigur, Kevin fremstod som pga. VR-udstyret, og så den uhyre menneskelige smerte og ensomhed, han gav udtryk for. Stor var min overraskelse derfor, da psykologen abrupt afbrød sessionen, og Kevin under applaus tog VR-udstyret af, mens han halvt grinende bemærkede, at "some of that nausea was real".

Som det fremgår af filmens rulletekster, er Kevin selv psykolog, og i filmen var han sammen med den kvindelige psykolog i færd med at demonstrere Virtual Iraq for en række militære psykologer, der deltog i den af ICT arrangerede workshop. ${ }^{\mathrm{I} 3} \mathrm{Groft}$ sagt var der altså tale om et rollespil inden for rammerne af et arrangement møntet på at markedsføre Virtual Iraq til et potentielt marked. Som bemærket af flere, herunder Farocki selv (Grinberg 2016), kan man tale om en form for brechtiansk verfremdungs-effekt i forbindelse med rollespillet og for den sags skyld også splitscreenæstetikken. Som beskuer rives man nemlig abrupt ud af sin empatiske identifikation med Kevin, da man opdager, at han blot har spillet en rolle. Og qua sammenstillingen af Kevins førstepersons-perspektiv på det simulerede landskab og filminstruktørens distanceret observerende blik på det rollespil, der opføres, opfordres man så at sige 


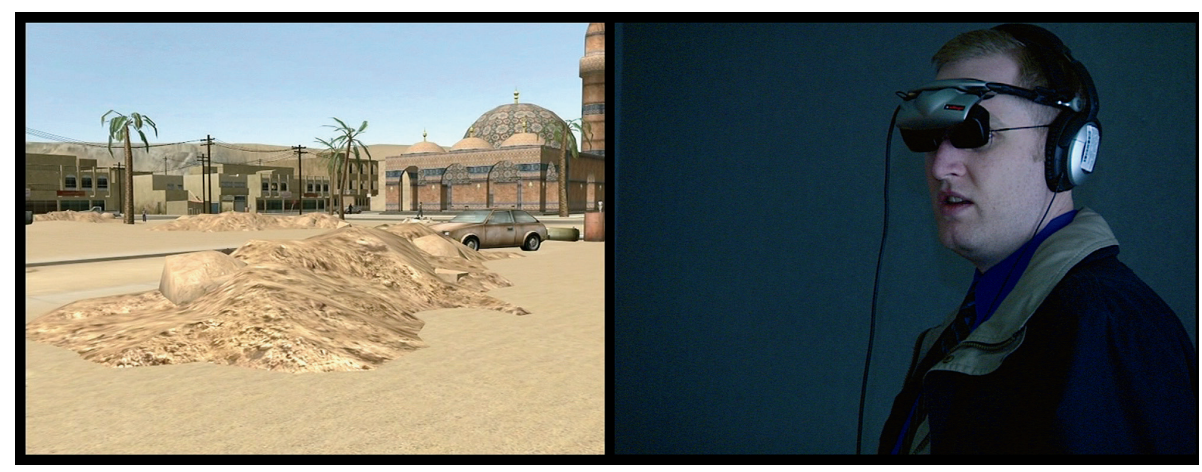

Harun Farocki: Serious Games. (C) Harun Farocki GbR, Berlin

til at forholde sig kritisk reflekterende til sin egen tilsyneladende hang til at lade sig forføre af rollespillet og de to psykologers iscenesættelse af virkeligheden.

Imidlertid skal installationens opfordring til at anskue det rollespil og den iscenesættelse, der foregår i Immersion, ikke læses som en Debord-inspireret modstilling mellem "sand virkelighed" og "falske skin-billeder". Som Anders Engberg-Pedersen har gjort opmærksom på, synes pointen derimod at være, at simulationen er blevet en konstituerende del af krigsvirkeligheden i dag: “As Farocki’s Serious Games makes evident, embodied immersive simulations form an integral part of what we must now think of as the military real" (Engberg 2017, 164). I tråd hermed kan man sige, at Farocki - idet han i Immersion lokker beskueren til at identificere sig med Kevin og godtage den rolle, han spiller, den virkelighed, han simulerer - viser, hvordan simulationen netop kan producere "virkelige" følelser og fornemmelser. Da jeg oplevede værket var min oplevelse af kvalme fx helt reel, ligesom min empatiske identifikation med det, jeg troede var en PTSD-ramt veteran, var det.

I Serious Games undersøger Farocki med andre ord, og lader beskueren selv erfare, den systematiske formning og kalibrering af soldaters perceptive og affektive apparat, der foregår i det "militær-industrielle-medie-underholdnings-netværk". Som vi så i Watson is Down, forberedes rekrutterne ikke bare taktisk, men også sensorisk på de oplevelser, der kan vente dem, således at de kan bevare et køligt overblik og måske endda optræde følelsesløse på slagmarken. Og som vi så i Immersion, kan PTSD-ramte soldater ved hjælp af simulationssystemer genbesøge den traumatiske krigsbegivenhed så mange gange, at den følelsesmæssige effekt af den til sidst aftager. Hvorefter de kan vende tilbage til slagmarken igen med den rette affektive indstilling! Hvad Farocki viser os i Serious Games er med andre ord, hvordan det manuskript, ud fra hvilket det amerikanske militær iscenesætter krigen og slagmarken, med hidtil uset præcision og takket være alliancen mellem militæret, akademia, og spil- og underholdningsindustrien nu kan implementeres direkte i soldatens forestillings- og sanseapparat.

\section{Dokumentarismens uvished}

Såvel Farockis Serious Games som Rimini Protokolls Situation Rooms udforsker, hvordan det simulerede og det virkelige i forbindelse med nutidens virtuelle krigsførelse er blevet dybt indfiltret i hinanden, samt hvordan slagmarken så at sige er 
rykket ind i og former subjektets sanseapparat. Farockis formelle greb til at undersøge dette er en split screen-æstetik, hvor vi dels ser den simulerede realitet indefra, dels produktionen af den udefra. Heroverfor indlejrer Rimini Protokoll i bogstavelig forstand beskueren i den immersive version af nutidens vidt forgrenede krigslandskab, som Situation Rooms' filmset-lignende installation udgør. Samtidig formaterer de, som vist ovenfor, ved hjælp af iPad'en et dobbeltblik hos publikum. I den forstand kan begge værker siges at benytte sig af en verfremdungs-inspireret strategi, hvor de, om end i varierende grad, dels inviterer beskueren til at investere sig fænomenologisk og emotionelt i det givne værk. Dels afbryder de denne identifikation ved at etablere en form for meta-niveau, hvor beskueren inviteres til at reflektere over sin interaktion med værket og i videre forstand de politiske, økonomiske og for Farockis vedkommende også massemediale strukturer, som værkets krigsbilleder er indlejret i. Således ligger det, som foreslået af Grinberg, lige for at koble Farockis nøje udtænkte vildledning af publikum i Immersion med den vildledning, der så at sige fandt sted af offentligheden, da den militære invasion af Irak i 2003 skulle legitimeres (Grinberg 2016). Mere specifikt manipulerer Farocki ved hjælp af tilsyneladende 'sandfærdige' videooptagelser beskueren til at tro på den rolle, den militære psykolog performer, og autenticiteten af den iscenesættelse, han er en del af. Dette greb ekkoer indirekte måden, hvorpå de politiske magthavere og det amerikanske militær systematisk anvendte grynede og uklare fotos som dokumentation og bevis for Iraks angivelige fremstilling af masseødelæggelsesvåben. Som bekendt kolporterede massemedierne villigt disse såkaldte beviser, der siden viste sig ikke at have rod i virkelighedens verden. Men fordi de blev tillagt status af uomtvistelige beviser kom de til at have meget virkelige konsekvenser!

De to værker er endvidere fælles om at benytte sig af en kombination af teatrale og dokumentariske greb. Som vist i det eksempel, hvor beskueren blev forført af Farocki til at tro, at de to psykologers rollespil var virkelighed, kan iscenesættelse og teatralitet netop være en effektiv måde at nærme sig virkelighedens, i dette tilfælde krigsvirkelighedens, simulerede karakter på. I den forbindelse bemærker Calvin Fagan, at Serious Games kan ses som et eksempel på et dokumentarisk værk, der så at sige har opdateret sin strategi, således at det frem for at prætendere at repræsentere virkeligheden 'objektivt' og 'sandfærdigt', matcher den nutidige virkeligheds kombination af virtuelle, simulerede og materielle elementer. Ifølge Fagan modsvarer denne form for dokumentarisme den 'virtuelle teori', som Der Derian efterlyser i sin bog om virtuel krig. Som Fagans udlægning af Der Derian:

46 'World politics is also in need of a virtual theory that explores how reality is seen, framed, read, and generated in the conceptualization and actualization of the global event', particularly through studying ways in which 'technical media constitute new virtual states of meaning and being.' [...] Serious Games engages with questions of virtuality, disembodiment, and performativity that permeate the simulative preparation and execution of recent wars. (Fagan 2013, 12)

Den kombination af teatrale og dokumentariske greb, der avendes i Serious Games, bliver med andre ord en adækvat måde at undersøge, hvordan der i nutidens si- 
mulerede krigsvirkelighed performativt bliver produceret følelser og emotioner, der ikke desto mindre er ganske virkelige for dem, de opleves af. Som fx den blanding af medlidenhed og kvalme, der blev fremkaldt i mig, da jeg iagttog den tilsyneladende PTSD-ramte soldats tilbagevenden til den for ham traumatiserende krigsbegivenhed.

Også Situation Rooms trækker på en kombination af på den ene side dokumentariske beretninger fra mennesker, der på den ene eller anden måde har tråde til våbenindustrien, og på den anden side iscenesatte, dramatiske situationer, hvori tilskueren inviteres til at performe. Imidlertid rejser det faktum, at de dokumentariske beretninger ikke er optaget i de tyve protagonisters hverdagslige omgivelser, men derimod i filminstallationens kunstige virkelighed en række spørgsmål: I hvor høj grad er beretningerne iscenesatte? I hvor høj grad er de billeder, vi dagligt bombarderes med af krig, konflikt og mennesker på flugt, manipulerede? Og videre: I hvor høj grad er vores daglige opførsel så at sige iscenesat og formet af en række på forhånd eksisterende kulturelle og sociale normer og diskurser? Snarere end at forfægte et træt postmodernistisk argument om virkeligheden som en endeløs kæde af simulakrer, synes pointen for Rimini Protokoll at være at fremhæve den uvished og mangel på stabilitet, som kan siges at være karakteristisk for virkeligheden og i videre forstand dokumentarismen i dag. I sit ofte citerede essay "The Uncertainty of Documentarism" hævder medieteoretiker og -kunstner Hito Steyerl, at i dag er: "uncertainty [...] not some shameful lack, which has to be hidden away, but instead constitutes the core reality of contemporary modes as such" (Steyerl 2011). Ifølge Steyerl forholder det sig ligefrem således, at jo mere grynet, pixeleret og uvist det dokumentariske billede er, jo større autenticitetseffekt udløser det. Og dette fordi verden i dag netop er karakteriseret ved uvished og manglende tiltro til det angiveligt objektive og neutrale dokument, der på sandfærdig vis skulle kunne afbilde samme verden. Mens denne uvished næppe kan siges at være et splinternyt fænomen, er den ikke desto mindre blevet intensiveret af fremkomsten af en global visuel, digital kultur, hvor sandsynligheden for, at billeder og dokumenter er blevet manipuleret, er større end det modsatte. Oversat til Rimini Protokolls immersive installation kommer Steyerls pointe omkring det dokumentariske billede med andre ord til udtryk igennem den tvivl eller uvished, som det faktum, at protagonisternes beretninger er optaget i filminstallationens kunstige virkelighed, udløser hos modtageren.

I forhold til både Farockis og Rimini Protokolls værker kan man i forlængelse heraf sige, at det dokumentariske aspekt ikke så meget fungerer som en garanti for, at de begivenheder, værkerne skildrer, er sandfærdige. Det centrale synes snarere at være, at værkerne i kraft af deres dokumentariske karakter udtrykker noget om de vilkår, hvorpå krig føres og sanses i den digitale og virtuelle tidsalder. Man kunne endda gå så vidt som til at hævde, at selve krigsbegivenheden forstået som et betydningsladet moment, der sætter en cæsur i forhold til hverdagen, er tæt på at forsvinde ikke bare i værkerne, men også i nutidens virtuelle krigsførelse. Som bl.a. Engberg-Pedersen (Engberg-Pedersen 2017, 173) har argumenteret for i forhold til Farockis Serious Games, er det således karakteristisk, at det er forberedelsen og sidenhen den terapeutiske bearbejdelse af krigen snarere end selve krigsbegivenheden, vi møder i værkernes simulerede virkeligheder. 
I forlængelse heraf kunne man argumentere for, at det såvel Serious Games som Situation Rooms gør igennem kombinationen af dokumentarisme og teatrale strategier, er at pege på krigen som begivenhed og at minde os om dens virkelige og materielle karakter. Denne insisteren på krigen som en virkelig begivenhed finder paradoksalt nok sted inden for kunstens midlertidige, diskursivt afgrænsede og iscenesatte rum. Et krigsteater en miniature kunne man måske kalde det. Men et krigsteater, hvor kunstnerne, jf. de to værkers komplekse rumlige og temporale dramaturgi, synes yderst bevidste om umuligheden af at operere med forud-diskonterede følgeslutninger. Ligesom krigsteknologierne konstant udvikler sig, må også den kunst, der forsøger at tage kritisk livtag med disse, udvikle sig. Og give afkald på uniforme ideer om virkelighed, sandhed og kritik.

\section{Noter}

I RMA er forbundet med det skift i krigsførelse, som anvendelsen af nye teknologier i kombination med forandrede militære doktriner og organisatoriske begreber medfører. Som påpeget i NATOs rapport om emnet fra 1998 hersker der uenighed om, hvor mange af sådanne revolutioner, der er forekommet historisk. Udtrykket benyttes imidlertid - og det er i denne betydning det bliver anvendt her - bl.a. om den betydelige teknologiske opgradering, der fandt sted i det amerikanske militær op igennem 1990'erne (http://www.iwar.org.uk/rma/resources/nato/ar299stc-e. html).

2 Se fx Brandon 2007, 13-35 og Bolt 2009, 62-64.

3 Det skal dog retfærdigvis bemærkes, at Clausewitz i modsætning til mange af sine samtidige netop modsætter sig ideen om, at man skulle kunne regne krigens væsen ud udelukkende ved hjælp af rationel logik. Således vier han en del af sin bog om krig til det, han kalder for krigens tåge og uforudsigelighed. Ligeledes anbefaler han, at man fordyber sig i litteratur og historie snarere end krigsspil spillet med terning på to-dimensionelle topografiske kort, hvis man ønsker at blive klogere på fænomenet krig (jf. Engberg-Pedersen 2017, 163).

4 Se bl.a. Brady 2012, Finburgh 2017 og Brady og Mantoan 2018.

5 En helt afgørende faktor i forhold til medie- eller billedkrigens centrale rolle i dag er dels fremkomsten i 90'erne af satellit-kanaler, der kunne live-transmittere krig og konflikt, dels udbredelsen af internettet og eksplosionen inden for de digitale medier og de deraf følgende muligheder for, at enhver kan cirkulere billeder og materiale via medieplatforme såsom som youtube eller facebook (Roger 2013, 11-14).

6 Se fx Kaye 2000, Bishop 2012, Alston 2013, Lehmann 2006.

7 Projektet havde premiere på Ruhr-triennalen i 2013. Jeg oplevede det selv i henholdsvis Paris maj 2014 og Berlin december 2014.

8 Man løber uvægerligt ind i en række problemer, når man skal forsøge at kategorisere Situation Rooms, for er det en immersiv forestilling, et "videostykke" eller en installation? Ligeledes kan man spørge til, om det giver mest mening at tale om en tilskuer, en co-aktør, en beskuer eller en gamer. For at holde fast i forbindelsen til teatermetaforen vælger jeg i det følgende termerne forestilling og beskuer.

9 Som flere teaterteoretikere, bl.a. Adam Alston, for nyligt har påpeget, kan man imidlertid spørge kritisk til, hvor meget frihed og autonomi beskuere reelt oplever i den lukrative forretning fx 
Punchdrunks forestillinger med tiden har forvandlet sig til (Alston 2016, 109-144). Er der ved nærmere eftersyn snarere tale om, at beskuere - aggressivt på jagt efter unikke, individuelle oplevelser med performerne - uafvidende reproducerer de oplevelsesøkonomiske strukturer og rationaler, som gennemsyrer virkeligheden omkring os?

Io Serious Games blev vist første gang i 2010 på Sao Paolo-biennalen. Jeg oplevede installationen i 2014 på Hamburger Bahnhof i Berlin.

II Se interview med Albert "Skip" Rizzo https://www.youtube.com/watch?v=OK893GmwuhM

I2 Se https://www.youtube.com/watch?v=OK893GmwuhM (tilgået 13 august 2018).

I3 Farockis beslutning om at anvende rollespil frem for at filme virkelige veteraner skyldtes delvis militærets angiveligt etisk motiverede forbud mod at dokumentere virkelige veteraners interaktion med VRET-programmet (Grinberg 2016).

\section{Litteratur}

Alston, Adam (2016): Beyond Immersive Theatre. Aesthetics, Politics and Productive Participation, London: Palgrave Macmillan.

Bishop, Claire (2012): Artitifical Hells: Participatory Art and the Politics of Spectatorship, London and New York: Verso.

Bolt, Mikkel (2009): “Om billedregimer, statsapparater og deres mulige kollaps", Jakob Jakobsen (red.): Billedpolitik: Brudstykker af samtidshistorien betragtet som tragedie, København: Nebula, s. 61-77.

Brady, Sara: (2012): Performance, Politics, and the War on Terror, London: Palgrave/Macmillan. Brandon, Laura (2007): Art \& War, London and New York: I.B. Tauris.

Butler, Judith (2009): Frames of War: When is Life Grievable?, London and New York: Verso. Clausewitz, Carl von (1976): On War, New Jersey: Princeton University Press.

Derian, James Der (2009): Virtuos War: Mapping the military-industrial-media-entertainment network, New York and London: Routledge.

Engberg-Pedersen, Anders (2017): “Technologies of Experience: Harun Farocki’s Serious Games and Military Aesthetics”, Boundary 2 44.4, s. 155-178.

Fagan, Calvin (2013): "Documenting Virtual War", inMedia 4, s. 1-12. https://journals.openedition. org/inmedia/733 (tilgået 14 august 2018).

Finburgh, Claire (2017): Watching War on the Twenty-First Century Stage: Spectacles of Conflict, London and New York: Bloomsbury.

Füssel, Marian (2008): “Theatrum Belli: Der Krieg als Inszenierung und Wissensschauplatz im 17. und 18. Jahrhundert", Metaphorik 14 (særhæfte Dimensionen der Theatrukm-Metapher), s. 205-230. Gade, Solveig (2018): "Reviving the Tradition of the Battle Painting: The Militarization of Danish Culture", Brady, Sara og Lindsey Mantoan (red.): Performance in a Militarized Culture, London/New York: Routledge, s. 136-151.

Grinberg, Daniel (2016): "Virtual Battlegrounds: The Multiple Realisms of Harun Farocki's Immersion”, Jump Cut: A Review of Contemporary Media 57, upagineret. https://www.ejumpcut.org/archive/jc57.2016/-GrinbergFarocki/index.html (tilgået 13. august 2018).

Halpern, Sue (2008): "Virtual Iraq: Using Simulation to treat a new Generation of traumatized Veterans”, The New Yorker 9. maj 2008. http://www.virtuallybetter.com/wp-content/uploads/2012/05/ New-Yorker2.pdf (tilgået 13. august 2018). 
Hirsch, Nikolaus(2013): “Theatrum Belli”, Rimini Protokoll: Situation Rooms, Bochum: Ruhrtriennale, s. 6-10.

Ibrügger, Lothar (1998): The Revolution in Military Affairs: Special Report, http://www.iwar.org.uk/ rma/resources/nato/ar299stc-e.html (tilgået 13-8 2018).

Kaldor, Mary (2007): Human Security: Reflections on Globalization and Intervention, Cambridge: Polity Press.

Kaye, Nick (2000): Site-Specific Art: Performance, Place and Documentation, London and New York: Routledge.

Lehmann, Hans-Thies (2006): Postdramatic Theatre, London and New York: Routledge.

Lenoir, Tim (2000): "All but War is Simulation: The Military-Entertainment Complex", Configurations 8.3 , s. 289-335.

Mirzoeff, Nicholas (2005) Watching Babylon: Thewar in Iraq and global visual culture, New York/ London: Routledge

Mitchell, W.J.T. (2011): Cloning War: The War of Images, 9/11 to the Present, Chicago: University of Chicago Press.

Oberender, Thomas (2006): Kriegstheater: Zur Zukunft des Politischen III, Berlin: Alexander Verlag Berlin.

Roger, Nathan (2013) Image Warfare in the War on Terror, London: Palgrave Macmillan.

Schipper, Imanuel (2017): "From Flaneur to Co-Creator: The Performative Spectator", Leeker, Martina, Imanuel Schipper og Timon Byes: Performing the Digital, Bielefeld: Transcript Verlag, s. 191209.

Steyerl, Hito (2007): "Documentary Uncertainty", A Prior 15, s. 300-308. Her citeret fra Re-visiones 2011 http://re-visiones.net/anteriores/spip.php\%3Farticle37.html (tilgået 14. august 2018).

Szondi, Peter (1967): Theorie des modernen Dramas, Berlin: Suhrkamp Verlag.

Verwoert, Jan (2011): "See What Shows - On the Practice of Harun Farocki”, Yilmaz Dziwior (red.):

Soft Montages, Kunsthaus Bregenz, s. 16-32.

Virilio, Paul (1989): War and Cinema: The Logistics of Perception, London/New York: Verso. 